\title{
Late Bronze Age Gaza: prestige production at el-Moghraqa
}

\author{
L. STeEl, B. Manley, J. Clarke \& M. SADEQ*
}

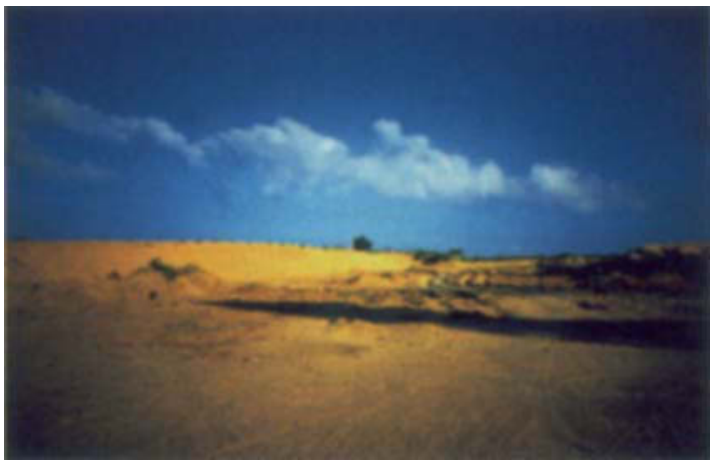

FIGURE 1 (above). View of el-Moghraqa, facing south.

FIGURE 2 (right). Cone fragment with prenomen of Tuthmose III.

FIGURE 3 (right, below). Bronze arrowheads.

The Bronze Age locale of el-Moghraqa lies in an area of farmland and sand dune north of the wadi Gaza, approximately $700 \mathrm{~m}$ north of Tell el-'Ajjul. This area, the Palestinian terminus of the 'Ways of Horus' (Oren $1987 ; 1993)$, was a key point of economic and military contact between Egypt and southern Palestine.

El-Moghraqa was discovered in 1996 (Clarke \& Steel 1999: 223-4) and the Gaza Research Project has completed two seasons of fieldwork at the site: survey in 1999 and preliminary soundings in 2000 . Unfortunately, given recent developments in Palestine, fieldwork has been suspended. A variety of Bronze Age artefacts were found in the survey: small quantities of pottery, Canaanite blades, ground stone fragments and finished prestige objects (carnelian beads and an alabaster kohl bottle). The exotica apes Egyptian New Kingdom luxuries of funerary character, a phenomenon also observed in the Dynasty XVIII cemetery at 'Ajjul (Steel 2002: 41-2, 45). However, this funerary aspect was not confirmed in subsequent excavations.

The most significant remains are fragments of terracotta cones stamped with the prenomen of Thutmose III (c. 1479-1425 BC). Two cone-fragments were also identified with broken stamps of his co-regent Hatshepsut's prenomen. Such cones are unique in SyroPalestine, but are extremely similar in form, construc-
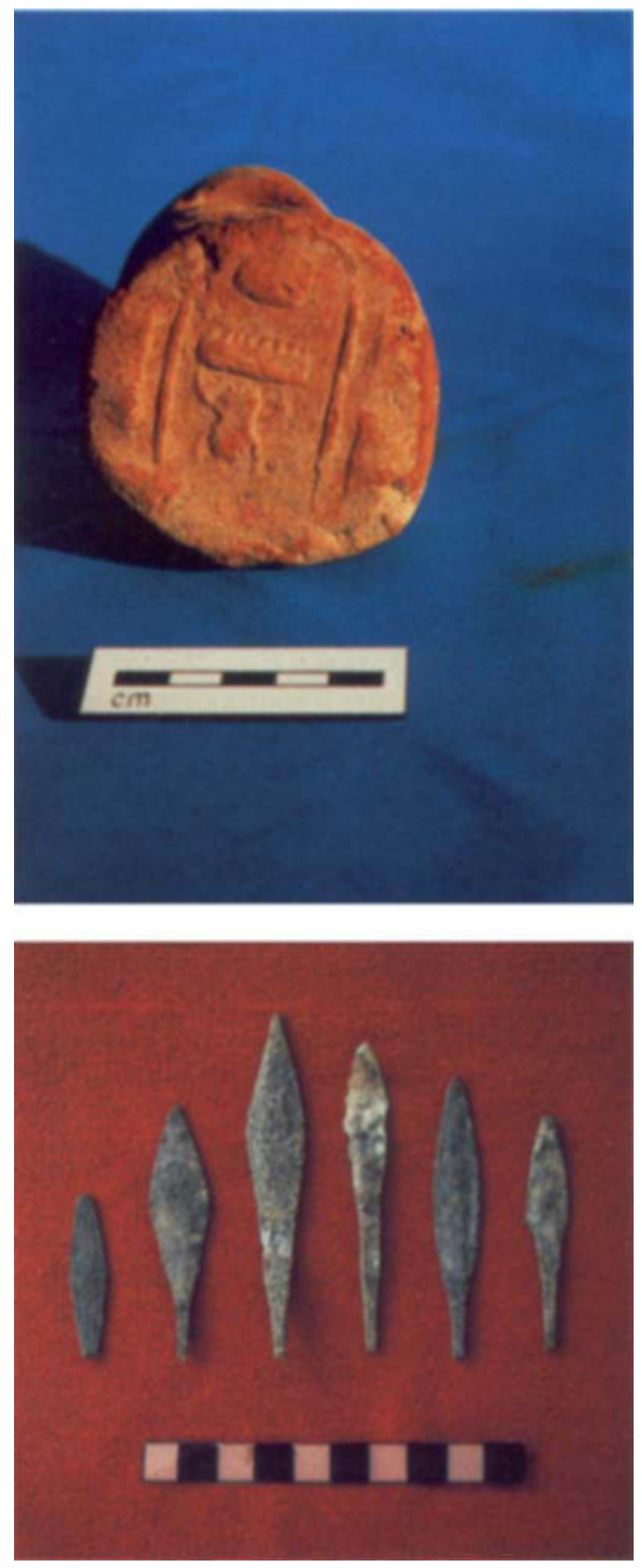

* Steel, Department of Archaeology, University of Wales Lampeter, Lampeter SA48 7ED, Dyfed, Wales. l.steel@lamp.ac.uk Manley, National Museums of Scotland, York Buildings, Queen Street, Edinburgh EH2 1JD, Scotland. billefc@aol.com Clarke, School of World Art Studies \& Museology, University of East Anglia, Norwich NR4 7TJ, England. joanne.Clarke@uea.ac.uk Sadeq, Department of Antiquities, PO Box 1088,Gaza City, Palestine. m.sadeq@marna.com 
tion and size to Egyptian Dynasty XVIII funerary cones (Davies \& MacAdam 1957), which are essentially a Theban phenomenon. Their specific significance is much debated, but they are certainly funerary, normally inserted in batches around the doorway of a tomb. The name and titles of the deceased would be stamped on the face, but no Egyptian examples include the name of the king. While our examples are contemporary with Egyptian funerary cones, their actual function at el-Moghraqa remains enigmatic.

Two occupation periods were identified in the exploratory soundings. The uppermost deposits date to the beginning of the Late Bronze Age and the lower levels to the Middle Bronze IIb-c phases. Occupation of el-Moghraqa therefore is contemporary with nearby 'Ajjul (Stewart 1974: 59-61). The Late Bronze Age remains were difficult to define in the very arid conditions. The cone fragments were found in a hard kurkar matrix, composed of compacted sand dunes. Associated finds included several bronze arrowheads and a carinated chalice, lying on a surface. Similar arrowheads were typical grave goods in the Dynasty XVIII cemetery at 'Ajjul (Petrie 1932: 8, plate XVII; 1933: 9, plate XXI/44-77; 1934: 10 , plate XXX/355-366).

The Middle Bronze II matrix comprised decomposed mudbrick, but no architectural remains were identified. However, the presence of a number of pits and a tabun (oven) suggests that excavation was concentrated within a courtyard. The associated material - some slag, haematite, unworked carnelian and mother of pearl, metal tools, and finished pieces of frit and jasper jewellery - indicate an outdoor production area. There was substantial pitting in the southern part of the site. The upper levels of one pit (Feature 310) were defined and sampled, but given constraints of time and money excavation was not completed. An Old Assyrian cylinder seal was found in the upper deposits (Collon 2002), associated with Middle Bronze Illb-c pottery. Although this is at odds with the earlier date of the cylinder seal, it is possible that the seal had been kept in circulation. Certainly, its surface exhibited substantial evidence of wear. Also in the pit were animal bones, fineware vessels and a burnt clay scarab sealing. Preliminary analysis attests to specialized deposition of the debris of feasting, but without further excavation the full implications of the context and use of the pit remain unclear.

Given the contemporaneity and proximity of elMoghraqa and 'Ajjul it appears that they belonged to a single polity. El-Moghraqa plausibly functioned as a satellite settlement of 'Ajjul, associated with the procurement of luxury materials and produc- tion of prestige items. Given the funerary aspect of much of this material, it seems probable that elMoghraqa serviced the Dynasty XVIII cemetery. The presence of occasional administrative documents implies centralized control of these activities.

\section{References}

CLARKE, J.T. \& L. STEEL. 1999. Demographic patterns and differential settlement in the Bronze Age landscape of Palestine, in I. Abu-Lughod, R. Heacock \& K. Nashef (ed.), The landscape of Palestine: equivocal poetry: 211-31. Birzeit: University of Birzeit.

Collon, D. 2002. The Old Assyrian cylinder seal from Gaza, Levant 34: 229-38.

DAVIES, N. \& M.F.L. MACADAM. 1957. Corpus of inscribed Egyptian funerary cones. Oxford: Oxford University Press.

OREN, E.D. 1987. The 'Ways of Horus' in North Sinai, in A.F. Rainey (ed.), Egypt, Israel, Sinai: archaeological and historical relationships in the biblical period: 69-119. Tel Aviv: Tel Aviv University.

1993. Northern Sinai, in E. Stern, A. Lewison-Gilboa \& J. Aviram (ed.), The new encyclopedia of archaeological investigations in the Holy Land 4: 1386-96. Jerusalem: Israel Exploration Society.

Petre, W.F. 1932. Ancient Gaza Il. Tell el Ajjul. London: British School of Archaeology in Egypt.

1933. Ancient Gaza III. Tell el Ajjul. London: British School of Archaeology in Egypt.

1934. Ancient Gaza IV. Tell el Ajjul. London: British School of Archaeology in Egypt.

STEEL, L. 2002. Consuming passions: a contextual study of the local consumption of Mycenaean pottery at Tell el- ${ }^{-} \mathrm{Ajjul}$, Journal of Mediterranean Archaeology 15: 25-51.

SteWART, J.R. 1974. Tell el 'Ajjul. The Middle Bronze Age remains. Göteborg: P. Åströms Förlag. SIMA 38.

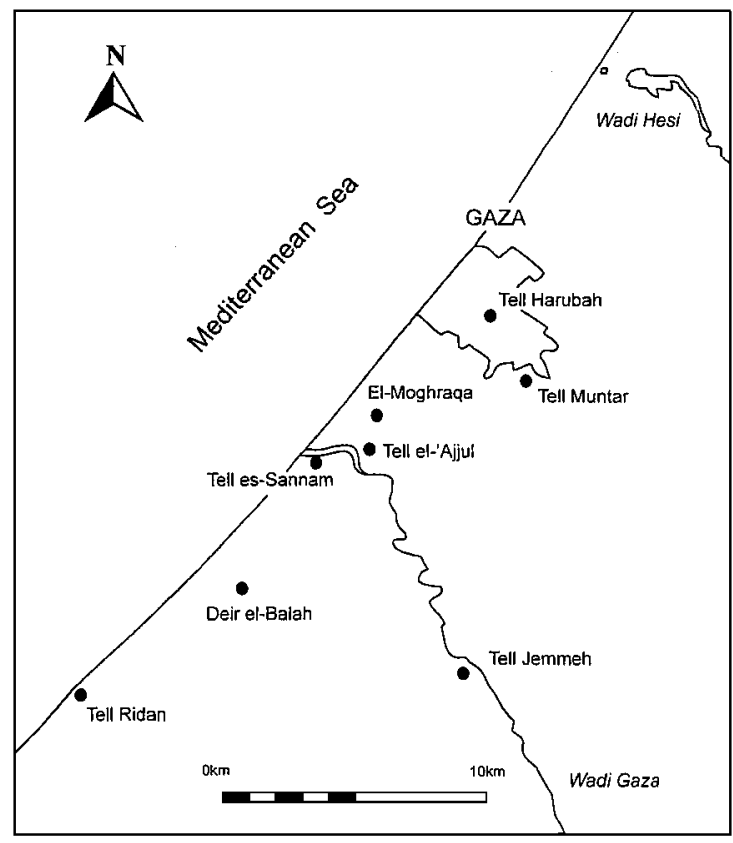

FIGURE 4. Map of Gaza regions showing location of el-Moghraqa. (Drawing D. Druce.) 